\title{
Pengaruh Hasil Tangkapan Ikan Tongkol (Euthynnus sp) dan Pendapatan Keluarga Nelayan Terhadap Tingkat Pendidikan Anak Keluarga Nelayan di Desa Seraya Timur, Kecamatan Karangasem, Kabupaten Karangasem
}

\author{
Ni Kadek Apriantari a*, I Gusti Ngurah Putra Dirgayusa a , Abd. Rahman As-syakur a \\ a Program Studi Ilmu Kelautan, Fakultas Kelautan dan Perikanan, Universitas Udayana, Kampus UNUD Bukit Jimbaran, Bali 80361, Indonesia \\ * Penulis koresponden. Tel.: +62-856-370-497-2 \\ Alamat e-mail: apriantari75@gmail.com
}

Diterima (received) 16 Juni 2017; disetujui (accepted) 13 Agustus 2017; tersedia secara online (available online) 15 Agustus 2017

\begin{abstract}
The East Seraya village has a potential of marines and fisheries, such as pelagic fish especially mackerel tuna fish according, production of tuna fish catch of $81 \%$ with the of catches $20.278,10$ ton/year. Research on the effect of catch fish and income of fisherman family on education level of children of fisherman family have been done at Seraya village. Data were collected in each group of fishermen from January to February 2017. The sample was taken using simple random method, with 89 respondents. Methods for the analysis of the effect of tuna catch and family income of fishermen on education level of children of fishermen family using multinomial logistic regression analysis with software SPSS (Statistical Package for Social Science. The educational level of the fishermen family has been completed at the level of fishermen children as follows; 2,2\% for elementary school 14,6 \% for junior high school, 33,7\% for senior high school, 31,5\% for diploma, and 18,0\%. Coefficient of $R$ square determination Cox and Snell value is 0,940 which means that mackerel tuna fishing results and the fishermen incomes are simultaneous with the education level of fishermen children in the amount of $94 \%$. Variable contribution of mackerel tuna fishing results (X1) which much affect the education level of fishermen children and the income of fishermen household (LnX2) affects the education level of fishermen children which is significant.
\end{abstract}

Keywords: tuna catch; income of fishing family; educational level of children of fishermen families

\begin{abstract}
Abstrak
Desa Seraya Timur memiliki potensi kelautan dan perikanan yang besar khususnya ikan tongkol yang merupakan salah satu ikan target nelayan, produksi hasil tangkapan ikan tongkol di Kabupaten Karangasem sebesar 81\% dengan jumlah tangkapan 20.278,10 Ton/tahun. Penelitian pengaruh hasil tangkapan ikan tongkol dan pendapatan keluarga nelayan terhadap tingkat pendidikan anak keluarga nelayan telah dilakukan di Desa Seraya Timur. Pengambilan data dilakukan di setiap kelompok nelayan pada bulan Januari sampai Februari 2017. Pengambilan sampel penelitian menggunakan metode acak sederhana, dengan jumlah 89 responden. Metode untuk analisis pengaruh hasil tangkapan ikan tongkol dan pendapatan keluarga nelayan terhadap tingkat pendidikan anak keluarga nelayan menggunakan analisis regresi logistik multinomial dengan software SPSS (Statistical Package for Social Science). Tingkat pendidikan anak keluarga nelayan telah diselesaikan pada jenjang SD persentase 2,2 \%, jenjang SMP persentase 14, $6 \%$, jenjang SMA persentase 33,7\%, jenjang D1 persentase 31,5\% dan jenjang S1 persentase $18,0 \%$. Pengaruh hasil tangkapan dan pendapatan terhadap tingkat pendidikan anak nelatan dilihat dari nilai $R$ square persamaan Cox and Snell adalah sebesar 0,940 berarti hasil tangkapan ikan tongkol dan pendapatan keluarga nelayan berpengaruh simultan terhadap tingkat pendidikan anak keluarga nelayan sebesar 94\%. Kontribusi variabel hasil tangkapan dan pendapatan keluarga nelayan berpengarh nyata terhadap tingkat pendidikan anak keluarga nelayan.
\end{abstract}

Kata Kunci: hasil tangkapan ikan tongkol; pendapatan keluarga nelayan; tingkat pendidikan anak keluarga nelayan 


\section{Pendahuluan}

Ikan Tongkol (Euthynnus sp) merupakan jenis ikan pelagis kecil dan perenang cepat yang hidup bergelombol (Sompie, 2011; Hajjej et al., 2010; Sulistyaningsih et al., 2014). Ikan tongkol mempunyai daerah penyebaran yang luas, umumnya mendiami perairan pantai dan oseanik (Mustaruddin, 2012; Yuniarta et al., 2017). Pola kehidupan ikan tongkol tidak bisa dipisahkan dari adanya berbagai kondisi lingkungan, parameter oceanografi seperti suhu permukaan laut, salinitas, konsentrasi klorofil laut, cuaca dan sebagainya serta perubahannya akan mempengaruhi kehidupan dan pertumbuhan ikan tongkol (Hendiarti et al., 2005; Rasyid, 2013). Ikan tongkol merupakan salah satu sumberdaya hayati laut yang memiliki potensi ekonomi yang cukup tinggi (Prayoga dkk., 2017), yang artinya ikan ini menjadi salah satu hasil perikanan yang menjadi target tangkapan nelayan (Pontoh, 2011; Ahmed et al., 2015).

Menurut DKP Kabupaten Karangasem (2016), harga ikan tongkol di Kabupaten Karangasem, khususnya pada Bulan Agustus dan September seharga Rp. 17.500/kg, harga ikan tongkol tidak selalu tetap melainkan berubah setiap musimnya (Johnson and Tamatamah, 2013). Musim ikan tongkol menurut Ilhamdi dkk. (2016) terjadi pada bulan Juli, Agustus, September, Oktober dan November, musim peralihan terjadi pada bulan Maret, April, Mei dan Juni, dan musim paceklik terjadi pada bulan Desember, Januari dan Februari.

Desa Seraya Timur memiliki potensi kelautan dan perikanan yang cukup besar khususnya ikan tongkol yang merupakan salah satu ikan target nelayan menurut BPS Kabupaten Karangasem (2016), produksi hasil tangkapan ikan tongkol di kabupaten karangasem sebesar $81 \%$ dari jumlah keseluruhan hasil tangkapan. Jumlah produksi hasil tangkapan ikan tongkol di Kabupaten Karangasem sebanyak 20.278,10 Ton/tahun.

Menurut DKP Kabupaten Karangasem (2016), Desa Seraya Timur merupakan Desa yang paling banyak memiliki kelompok nelayan di seluruh Kabupaten Karangasem, dengan jumlah 26 kelompok nelayan yang tersebar dari masingmasing Banjar yang berada di Desa Seraya Timur diantaranya Banjar Tukad Tiis, Banjar Gili Selang, Banjar Tukad Item, Banjar Pemujan Kangin, Banjar Batu Kori, Banjar Tukad dan Banjar Tanah Barak.

Dari tingkat pendidikan anak keluarga nelayan yang bisa ditempuh pada jenjang tingkat SD, SMP, SMA, D1 serta S1 menurut hasil observasi perkembangan tingkat pendidikan anak keluarga nelayan dapat dipengaruhi oleh beberapa faktor diantaranya faktor hasil tangkapan ikan tongkol dan pendapatan keluarga nelayan (Wasak, 2012).

Menurut Basrowi dan Juariyah (2010), hasil tangkapan akan berpengaruh signifikan terhadap pendapatan nelayan setiap kenaikan $1 \%$ hasil tangkapan akan menaikan pendapatan nelayan. Di Desa Seraya Timur belum pernah ada yang meneliti tentang pengaruh dari hasil tangkapan dan pendapatan terhadap tingkat pendidikan maka perlu adanya penelitian tentang "Pengaruh Hasil Tangkapan Ikan Tongkol dan Pendapatan Keluarga Nelayan Terhadap Tingkat Pendidikan Anak Keluarga Nelayan Di Desa Seraya Timur Kecamatan Karangasem Kabupaten Karangasem"

\section{Metode Penelitian}

\subsection{Waktu dan Lokasi Penelitian}

Penelitian dilakukan di Desa Seraya Timur, Kecamatan Karangasem, Kabupaten Karangasem. Dengan pengambilan sampel di masing-masing kelompok nelayan, dimana Terdapat 26 kelompok nelayan dari 9 Banjar yang berada di Desa Seraya Timur.

Penelitian ini dilakukan selama kurun waktu 4 bulan yang dimulai dari bulan Januari sampai bulan April 2017. Pengambilan data dilakukan pada bulan Januari sampai bulan Februari 2017 kemudian pengolahan data serta analisis data dilakukan pada bulan Maret sampai bulan April 2017. Peta lokasi penelitian dapat dilihat pada Gambar 1.

\subsection{Alat dan Bahan}

Penelitian yang digunakan pada penelitian ini adalah penelitian yang menggunakan teknik 


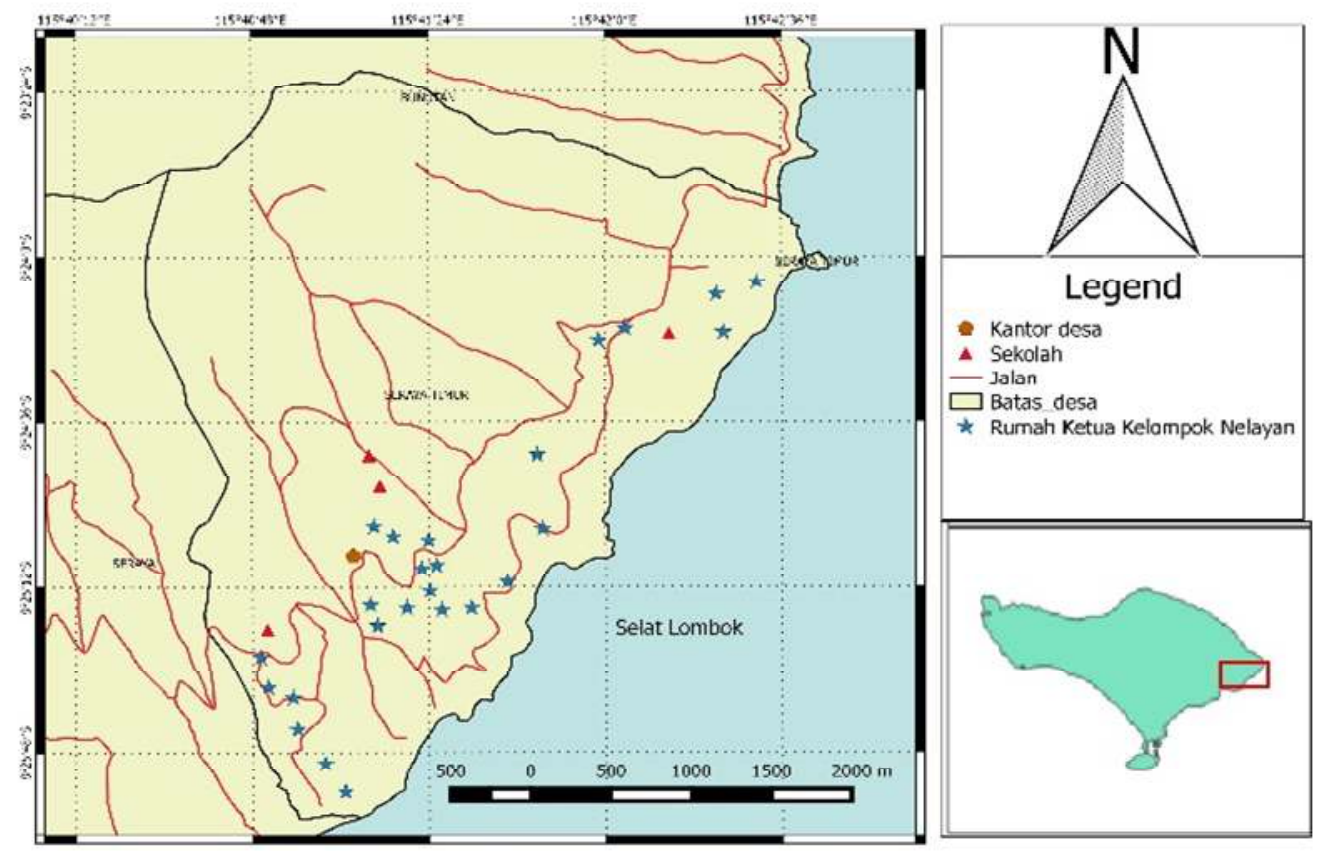

Gambar 1. Peta Lokasi Penelitian

wawancara kepada responden yang terpilih yaitu nelayan yang berada di Desa Seraya Timur, dimana wawancara langsung kepada responden berdasarkan pertanyaan yang telah disiapkan melaluai angket kuesioner terbuka. Alat tulis untuk mencatat hasil pengamatan di lapangan dan Komputer untuk mengolah data dengan software SPSS (Statistical Package for Social Science).

\subsection{Variabel Penelitian dan Definisi Oprasional}

\section{Variabel Penelitian}

Berkaitan dengan topik penelitian, maka variabel dalam penelitian ini adalah : Hasil tangkapan ikan tongkol, Pendapatan keluarga nelayan dan Pendidikan anak nelayan.

\section{Definisi Oprasional Variabel}

a. Hasil tangkapan yang dikaji dalam penelitian ini berupa hasil tangkapan ikan tongkol ratarata perbulan.

b. Pendapatan yang dikaji yaitu total pendapatan rumah tangga yang berasal dari hasil. tangkapan ikan tongkol, pendapatan dari usaha bersama lainya, pendapatan anggota rumah tangga selama sebulan dihitung dalam satuan rupiah. c. Pendidikan yang dikaji yaitu pendidikan tertinggi yang ditamatkan anak nelayan dengan mengukur tahun sukses.

\subsection{Metode dan Instrumen Pengumpulan Data}

a. Survei dilakukan ke masing-masing ketua kelompok nelayan untuk mengetahui data responden kemudian mendatangi rumah nelayan yang menjadi objek penelitian untuk di wawancara.

b. Observasi Penelitian ini menggunakan teknik observasi partisipan yaitu peneliti terlibat langsaung.

c. Dokumentasi yang dicari dalam penelitian ini adalah monografi desa, foto yang berkaitan dengan nelayan, foto penelitian.

d. Metode wawancara yang digunakan adalah metode wawancara berstruktur yaitu dengan terlebih dahulu menyusun daftar pertanyaan kuesioner. Untuk memperoleh data primer mengenai kondisi hasil tangkapan ikan tongkol, pendapatan nelayan dan tingkat pendidikan anak nelayan.

\subsection{Populasi dan Sampel}

Populasi dalam penelitian ini adalah kelompok nelayan yang terdiri dari 26 kelompok nelayan yang berada di masing-masing Banjar di Desa 
Tabel 1

Distribusi Pengambilan Sampel Responden Penelitian

\begin{tabular}{|c|c|c|c|c|}
\hline No & Nama Kelompok Nelayan & Alamat Banjar & Jumlah Anggota & Sampel \\
\hline 1 & Segara Pura Mina & Tukad Tiis & 35 orang & 3 \\
\hline 2 & Segara Lestari Indah & Tukad Tiis & 25 orang & 2 \\
\hline 3 & Segara Abadi Indah & Tukad Tiis & 23 orang & 2 \\
\hline 4 & Baruna Mukti & Tukad Tiis & 24 orang & 2 \\
\hline 5 & Batu Bingkung & Tukad Tiis & 21 orang & 2 \\
\hline 6 & Wiratama Enjung Sari & Batu Kori & 37 orang & 4 \\
\hline 7 & Segara Utama & Batu Kori & 46 orang & 5 \\
\hline 8 & Asem Sari & Batu Kori & 22 orang & 2 \\
\hline 9 & Darma Lautan III & Batu Kori & 44 orang & 4 \\
\hline 10 & Segara Wangi I & Gili Selang & 66 orang & 7 \\
\hline 11 & Segara Wangi II & Gili Selang & 54 orang & 5 \\
\hline 12 & Segara Wangi III & Gili Selang & 61 orang & 6 \\
\hline 13 & Segara Wangi & Gili Selang & 22 orang & 2 \\
\hline 14 & Tunas Mina Segara & Gili Selang & 23 orang & 3 \\
\hline 15 & Suka Makmur Bina Usaha & Pemujan Kangin & 26 orang & 4 \\
\hline 16 & Suka Makmur Segara Abadi & Pemujan Kangin & 32 orang & 4 \\
\hline 17 & Suka Makmur Sejati & Pemujan Kangin & 30 orang & 3 \\
\hline 18 & Suka Makmur Trikarya & Pemujan Kangin & 31 orang & 4 \\
\hline 19 & Suka Makmur Wisnu rejeki & Pemujan Kangin & 31 orang & 3 \\
\hline 20 & Kartika Bahari I & Tukad Item & 21 orang & 2 \\
\hline 21 & Kartika Bahari II & Tukad Item & 21 orang & 3 \\
\hline 22 & Kartika Bahari III & Tukad Item & 21 orang & 3 \\
\hline 23 & Kartika Bahari IV & Tukad Item & 22 orang & 3 \\
\hline 24 & Giri Mandara Sari & Tukad Item & 40 orang & 5 \\
\hline 25 & Batu Tengah & Tukad Buah & 30 orang & 4 \\
\hline 26 & Bina Sejahtera & Tanah Barak & 19 orang & 2 \\
\hline
\end{tabular}

Seraya Timur Kecamatan Karangasem Kabupaten Karangasem.

\subsubsection{Penentuan Jumlah Sampel}

Penentuan jumlah sampel ditentukan dengan menggunakan rumus slovin. Adapun rumus tersebut adalah sebagai berikut:

$$
n=\frac{N}{1+N e 2}
$$

Dimana:

$$
\begin{aligned}
\mathrm{n} \quad= & \text { jumlah sampel } \\
\mathrm{N} \quad= & \text { jumlah populasi } \\
\mathrm{e} \quad= & \text { batas toleransi kesalahan (error tolerance) } \\
& \text { dimana batas toleransi kesalahan } \\
& \text { ditetapkan } 10 \% .
\end{aligned}
$$

dalam penelitian ini populasi berjumlah 827 nelayan dengan margin error atau taraf kesalahan $10 \%$, sehingga diperoleh sampel sebesar 89,21 nelayan maka dibulatkan menjadi 89 nelayan.

\subsubsection{Teknik Pengambilan Sampel}

Teknik pengambilan sampel dalam penelitian ini yaitu menggunakan metode acak sederhana (Simple Random Sampling) yaitu setiap anggota dari populasi memiliki kesempatan dan peluang yang sama untuk dipilih sebagai sampel penelitian. Dimana dalam penelitian ini pengambilan responden dilakukan dari 26 kelompok nelayan dimana pengambilan sampel di masing-masing kelompok nelayan di Desa Seraya Timur menggunakan metode acak sederhana dengan taraf pengambilan $10 \%$ dari setiap populasi di kelompok nelayan untuk mewakili setiap kelompok. Distribusi yang diperoleh dengan menggunakan teknik tersebut dapat dilihat pada Tabel 1.

\subsection{Teknik Analisis Data}

\subsubsection{Analisis Deskritif}

Statistik deskritif memberikan gambaran atau deskripsi suatu data yang dilihat dari nilai rata-rata (mean), maksimum, minimum Untuk 
mendapatkan hasil tangkapan ikan tongkol dalam kurun waktu per bulan dan pendapatan keluarga nelayan per bulan, digunakan perhitungan nilai rata-rata dengan rumus sebagai berikut:

$$
X=\frac{\sum X}{N}
$$

Dimana:

$X \quad$ : Nilai rata-rata

$\sum X \quad$ : Jumlah seluruh data

$\mathrm{N} \quad$ : Banyak data

\subsubsection{Analisis Tingkat Pendidikan Anak Nelayan}

Untuk mengetahui tingkat pendidikan, digunakan teknik perhitungan deskriptif yaitu dengan mencari presentase tingkat pendidikan. Rumus untuk mencari presentase tingkat pendidikan adalah sebagai berikut:

$$
P=\frac{F}{N} X 100 \%
$$

Dimana:

$$
\begin{array}{ll}
\mathrm{P} & =\text { Persentase } \\
\mathrm{F} & =\text { Frekuensi } \\
\mathrm{N} & =\text { Jumlah Responden }
\end{array}
$$

Penggolongan tingkat pendidikan anak nelayan dengan menggunakan pengkodean, dimana kode tingkat pendidikan dapat dilihat pada tabel 2.

Tabel 1

Tabel Kode Tingkat Pendidikan.

\begin{tabular}{cc}
\hline Tingkat Pendidikan & Kode \\
\hline Tidak Sekolah & 0 \\
SD & 1 \\
AMP & 2 \\
SMA & 3 \\
D1 & 4 \\
S1 & 5 \\
\hline
\end{tabular}

\subsubsection{Analisis Regresi Logistik Multinominal}

\section{a. Analisis Kelayakan Data}

Langkah pertama adalah menguji kelayakan data, uji khi-kuadrat Pearson digunakan untuk mengukur kekuatan hubungan linier. Dimana jika nilai probabilitas signifikansi lebih besar dari tingkat signifikansi $\alpha$ : 0,05 (sig. > 0,05), maka $\mathrm{H}_{0}$ ditolak dan $\mathrm{H}_{1}$ diterima. Dengan menggunakan analisis software SPSS (Statistical Package for Social Science).

b. Koefisien Determinasi

Digunakan untuk mengetahui seberapa besar pengaruh variabel hasil tangkapan ikan tongkol (X1) dan variabel pendapatan keluarga nelayan (LnX2) terhadap tingkat pendidikan anak keluarga nelayan (Y). Dilihat dari $R$ Square pada persamaan Cox and Snell, dikatakan baik jika $R$ Square diatas $\alpha$ 0,05 . Dengan menggunakan analisis software SPSS (Statistical Package for Social Science)

\section{c. Kontribusi Setiap Variabel Bebas Terhadap} Variabel Terikat

Dilihat dari persamaan likelihood (maximum likelihood methods) dengan memasukan data hasil tangkapan ikan tongkol (X1), pedapatan keluarga nelayan (LnX2) dan tingkat pendidikan anak nelayan (Y). Dikatakan berpengaruh nyata jika nilai signifikasinya < Alfa 0,05 dari setiap variabel bebas terhadap variabet terikat. Dengan menggunakan analisis software SPSS (Statistical Package for Social Science)

\section{Hasil dan Pembahasan}

\subsection{Hasil Tangkapan Nelayan}

Hasil tangkapan ikan tongkol dipengaruhi oleh beberapa faktor salah satu dipengaruhi oleh musim, setiap musim dapat dikasifikasikan diantaranya musim penangkapan yang terjadi pada bulan Juli, Agustus, September, Oktober dan November (Septanto dan Tenny, 2012). Musim peralihan terjadi pada bulan Maret, April, Mei dan Juni. Dan musim paceklik terjadi pada bulan Desember, Januari dan Februari. Musim penangkapan hasil tangkapan ikan tongkol tinggi, jika musim peralihan hasil tangkapan ikan menurun sedangkan musim paceklik hasil tangkapan sangat rendah dan juga cuaca yang tidak mendukung untuk para nelayan pergi melut.

Dari data hasil wawancara terhadap responden, dapat dijelaskan bahwa dari ke 26 kelompok nelayan rata-rata hasil tangkapan dapat dijelaskan bahwa ikan tongkol yang paling tinggi yaitu kelompok nelayan Segara Abadi Indah sebanyak 1884 ekor/bulan, kemudian rata-rata hasil tangkapan ikan tongkol yang paling rendah yaitu kelompok nelayan Darma Lautan III sebanyak 


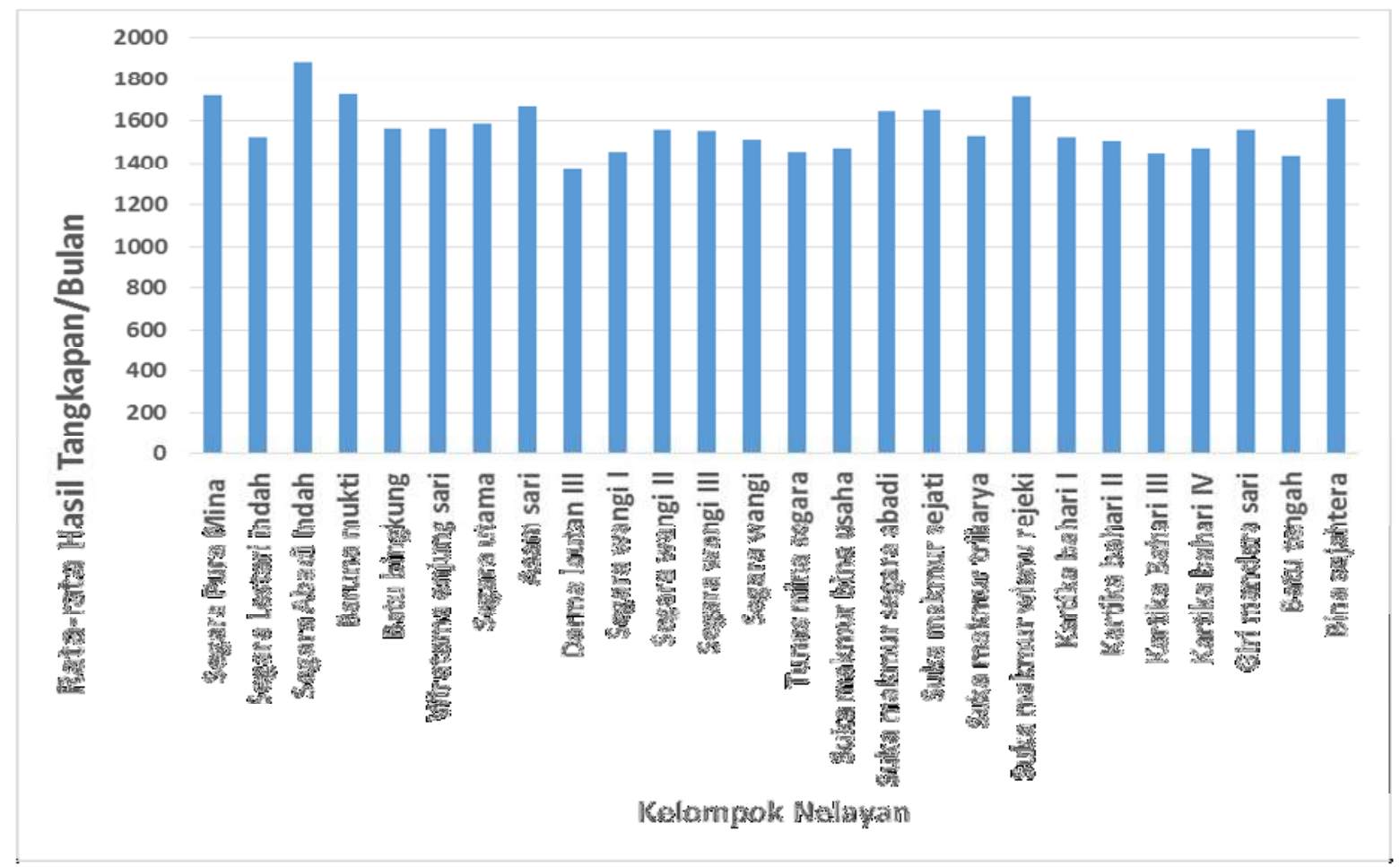

Gambar 2. Hasil Tangkapan Ikan Tongkol di Masing-masing Kelompok Nelayan

1364 ekor/bulan. Lebih jelasnya dapat dilihat pada Gambar 2.

\subsection{Hasil Pendapatan Total Keluarga Nelayan}

Pendapatan nelayan merupakan hasil dari menangkap ikan dan hasil pendapatan dari pekerjaan sampingan dari anggota keluarga nelayan. Pendapatan nelayan di Desa Seraya Timur dapat bersumber dari pendapatan hasil tangkapan ikan tongkol, pekerja sampingan seperti pengerajin (anyaman ata), buruh tani, berternak, buruh bangunan dan wirausaha. Ratarata pendaptan total nelayan yang paling tinggi yaitu kelompok nelayan Baruna Mukti dan Segara Abadi Indah sebesar Rp. 5.100.000/bulan, kemudian rata-rata pendapatan total nelayan yang paling rendah yaitu kelompok nelayan Kartika Bahari IV sebesar Rp. 3.181.000/bulan. lebih jelas dapat dilihat pada Gambar 3.

\subsection{Rata-rata Hasil Tangkapan dan Pendapatan}

Berdasarkan wawancara yang dilakukan terhadap 89 responden di Desa Seraya Timur Kecamatan Karangasem, Kabupaten Karangasem yang dianalisis secara deskritif. Variabel yang diteliti adalah pengaruh hasil tangkapan ikan tongkol dan pendapatan keluarga nelayan terhadap tingkat pendidikan anak keluarga nelayan yang berjenjang.

Hasil tangkapan ikan tongkol dari 89 responden di Desa Seraya Timur rata-rata sebanyak 1550 ekor/bulan dengan total pendapatan rata-rata sebesar Rp. 3.984.764/bulan tingkat pendidikan anak keluarga nelayan dominan pada tingkat SMA. Total pendapatan keluarga nelayan rata-rata maksimum sebesar Rp.5.970.000/bulan dengan hasil tangkapan maksimum sebanyak 2040 ekor/bulan, dan tingkat pendidikan maksimum yang mampu ditempuh S1. Sedangkan dari 89 responden total pendapatan keluarga nelayan minimum sebesar Rp.2.100.000/bulan dengan jumlah hasil tangkapan ikan tongkol minimum sebanyak 1050 ekor/bulan, tingkat pendidikan anak keluarga nelayan minimum yang dapat ditempuh pada jenjang SD. Dapat dilihat pada Tabel 3.

\subsection{Pengaruh Hasil Tangkapan dan Pendapatan}

\subsubsection{Klasifikasi Tingkat Pendidikan}

Tabel klasifikasi menunjukkan kekuatan prediksi dari model regresi untuk memprediksi probabilitas tingkat pendidikan. Kekuatan 


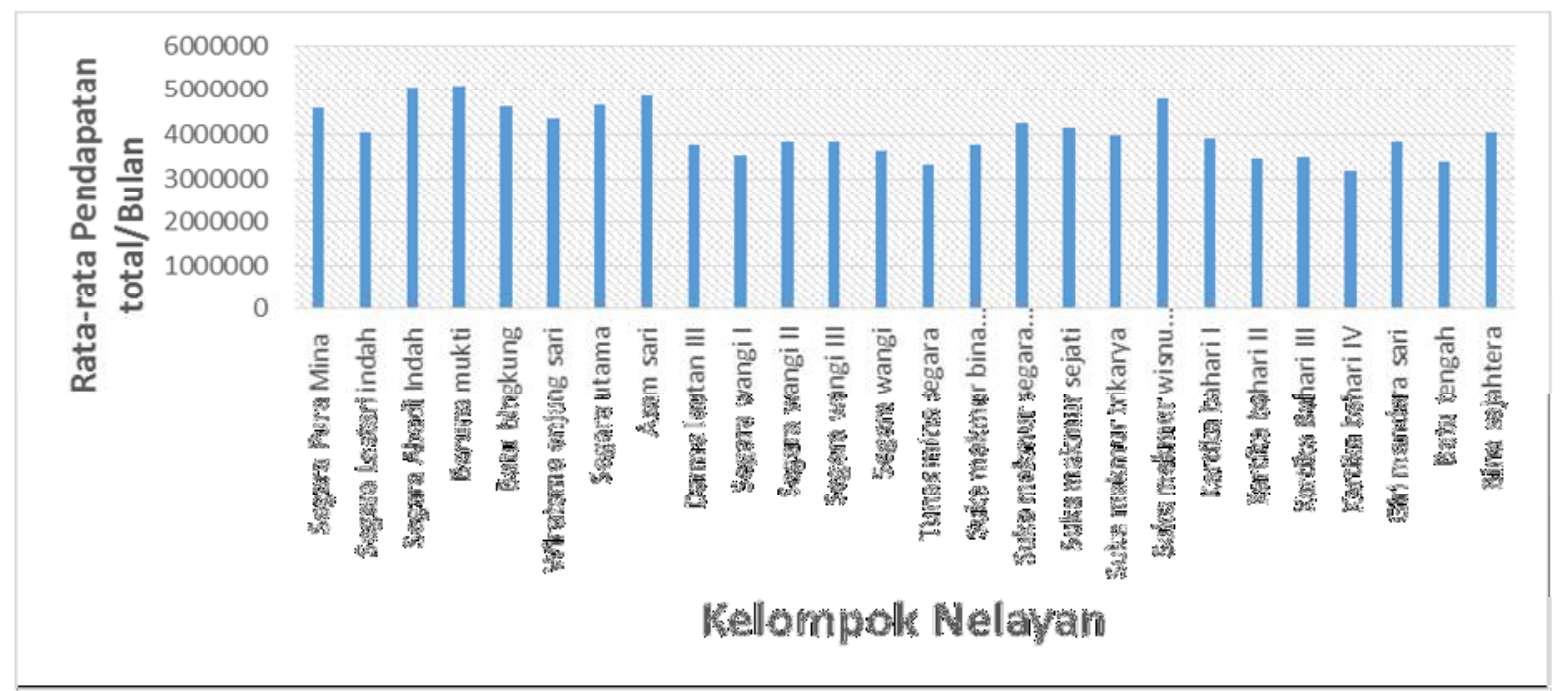

Gambar 3. Total Pendapatan Nelayan di masing-masing Kelompok Nelayan

prediksi dari model regresi untuk memprediksi kemungkinan terjadinya variabel terikat dinyatakan dalan persen. Hasil tabel klasifikasi ditampilkan dalam Tabel 4.

Tabel 3

Hasil tangkapan dan Pendapatan nelayan.

\begin{tabular}{ccccc}
\hline Variabel & $\mathrm{N}$ & Minimum & Maksimum & Mean \\
\hline $\begin{array}{c}\text { Total } \\
\text { pendapatan/ } \\
\text { bulan }\end{array}$ & 89 & 2.100 .000 & 5.970 .000 & 3.984 .000 \\
$\begin{array}{c}\text { Hasil } \\
\text { Tangkapan/ } \\
\text { bulan }\end{array}$ & 89 & 1050 & 2040 & 1550 \\
$\begin{array}{c}\text { Tingkat } \\
\text { Pendidikan } \\
\text { Anak }\end{array}$ & 89 & SD & S1 & SMA \\
\hline
\end{tabular}

Tabel 4

Klasifikasi Tingkat Pendidikan

\begin{tabular}{cccccc}
\hline Pendidikan & SD & SMP & SMA & D1 & S1 \\
\hline SD & 2 & 0 & 0 & 0 & 0 \\
SMP & 0 & 13 & 0 & 0 & 0 \\
SMA & 0 & 0 & 30 & 0 & 0 \\
D1 & 0 & 0 & 0 & 28 & 0 \\
S1 & 0 & 0 & 0 & 0 & 16 \\
Persentase & $2,2 \%$ & $14,6 \%$ & $33,7 \%$ & $31,5 \%$ & $18,0 \%$ \\
\hline
\end{tabular}

Tabel 4 menunjukkan kemampuan prediksi model secara menyeluruh Dengan tingkat pendidikan SD kode 1 dengan jumlah anak yang menempuh 2 orang anak yaitu $2,2 \%$. SMP kode 2 dengan jumlah 13 anak yaitu 14, $6 \%$. Tingkat SMA dengan kode 3 dengan jumlah anak 30 orang yaitu 33,7\%. Kemudian dengan D1 kode 4 yang sudah menempuh jenjang tersebut sebanyak 28 orang yaitu 31,5\% dan untuk jenjang S1 kode 5 sedah ditempuh sebanyak 16 orang yaitu $18,0 \%$ dengan keseluruhan 100\%, untuk tingkat pendidikan anak keluarga neayan rata-rata sudah menepuh bangku SMA yang telah diselesaikan.

\subsubsection{Analisis Kelayakan Model}

Untuk mengetahui informasi apakah data yang didapat layak. dapat diketahui dari nilai chi square lebih kecil sehingga dihasilkan nilai signifikan $(\mathrm{P}>0,05)$. Nilai statistik chi square pada pearson sebesar 0,00 dengan probabilitas signifikansi 1,00 jauh di atas 0,05. Dengan demikian dapat disimpulkan bahwa model mampu memprediksi nilai observasinya atau dapat dikatakan model dapat diterima karena cocok dengan data observasinya.

\subsubsection{Koefisien Determinasi}

Besarnya nilai koefisien determinasi pada model regresi logistik ditunjukkan dengan nilai Cox and Snell $R$ square. Berdasarkan hasil pengujian yang ditunjukkan pada nilai Cox and Snell $R$ square adalah sebesar 0,940 yang berarti bahwa hasil tangkapan ikan tongkol dan pendapatan nelayan pengaruh simultan terhadap tingkat pendidikan anak keluarga nelayan sebesar $94 \%$ atau 
variabilitas variabel dependen yang dapat dijelaskan oleh variabel independen adalah sebesar 94\%, sedangkan sisanya sebesar $6 \%$ dijelaskan oleh variabel-variabel lain di luar model penelitian.

3.3.4. Kontribusi Variabel Bebas terhadap Variabel Terikat

Tabel likelihood ratio test dapat menunjukkan kontribusi setiap variabel independen terhadap model, tingkat signifikansinya dapat dilihat pada Tabel 5.

Tabel 5

Kontribusi variabel bebas terhadap variabel terikat

\begin{tabular}{|c|c|c|c|c|}
\hline & \multirow{2}{*}{$\begin{array}{l}\text { Model Fitting } \\
\text { Criteria } \\
-2 \text { Log } \\
\text { Likelihood of } \\
\text { Reduced } \\
\text { Model }\end{array}$} & \multicolumn{3}{|c|}{ Likelihood Ratio Tests } \\
\hline & & $\begin{array}{l}\text { Chi } \\
\text { Square }\end{array}$ & df & Sig. \\
\hline Pendapatan & 7,638 & 17,638 & 88 & $0,016^{*}$ \\
\hline $\begin{array}{c}\text { Hasil } \\
\text { Tangkapan }\end{array}$ & 89,168 & 89,168 & 88 & $0,000^{* *}$ \\
\hline
\end{tabular}

${ }^{*}$ Nyata ${ }^{* *}$ Sangat Nyata

Berdasarkan tabel 5 Likelihood ratio test menunjukan kontribusi setiap variabel independen terhadap dependen atau model, dapat dijelaskan bahwa variabel hasil tangkapan ikan tongkol (X1) signifikan 0,000 atau $<0,05$ yang artinya berpengaruh sangat nyata terhadap tingkat pendidikan anak keluarga nelayan dan pendapatan keluarga nelayan (LnX2) signifikan 0,016 atau $<0,05$ berpengaruh nyata pada tingkat pendidikan anak keluarga nelayan.

Hipotesis dapat dijelaskan bahwa hasil tangkapan ikan tongkol dan total pendapatan kelurga nelayan berpengaruh signifikan terhadap tingkat pendidikan anak keluarga nelayan di Desa Seraya Timur Kecamatan Karangasem Kabupaten karangasem.

\section{Simpulan}

Berdasarkan hasil penelitian dan pembahasan, dapat diambil kesimpulan bahwa:

1. Terdapat rata-rata hasil tangkapan ikan tongkol 1550 ekor/bulan dengan hasil pendapatan rata-rata sebesar Rp. 3.984.000/ bulan dari 89 responden dengan rata-rata tingkat pendidikan anak keluarga nelayan pada jenjang SMA. Dari masing-masing kelompok nelayan paling tinggi hasil tangkapan yaitu kelompok nelayan Segara Abadi Indah dan Pendapatan paling tinggi yaitu kelompok nelayan Baruna Mukti yang berada di Desa Seraya Timur Kecamatan Karangasem Kabupaten Karangasem.

2. Terdapat pengaruh yang signifikan antara hasil tangkapan ikan tongkol dan pendapatan nelayan terhadap Tingkat pendidikan anak dilihat dari Cox and Snell $R$ square sebesar 0,94\%, yang dapat dijelaskan pengaruh oleh semua variabel independen adalah sebesar $94 \%$ dan sisanya $6 \%$ dijelaskan oleh variabel lain. Kontribusi setiap variabel independen terhadap dependen dimana variabel hasil tangkapan ikan tongkol signifikan sangat nyata sebesar 0,000 terhadap tingkat pendidikan anak keluarga nelayan dan Pendapatan total keluarga nelayan signifikan nyata sebesar 0,016 terhadap tingkat pendidikan anak keluarga nelayan.

\section{Ucapan terimakasih}

Penulis mengucapkan terima kasih kepada Dinas Kelautan dan Perikanan (DKP) Kabupaten Karangasem yang telah menyediakan data kelompok nelayan di Desa Seraya Timur, terimakasih kepada kelompok nelayan yang sudah bersedia menjadi responden penelitian, serta seluruh pihak yang telah memberikan saran dan bingbingan dalam pembuatan tulisan ini. Terima kasih juga penulis ucapkan kepada keluarga besar Fakultas Keautan dan Perikanan Universitas Udayana serta teman-teman Ilmu Kelautan satu angkatan yang tidak dapat penulis sebutkan satu persatu atas segala bantuan yang telah diberikan.

\section{Daftar Pustaka}

Ahmed, Q., Yousuf, F., Sarfraz, M., Mohammad Ali, Q., Balkhour, M., Safi, S. Z., \& Ashraf, M. A. (2015). Euthynnus affinis (little tuna): fishery, bionomics, seasonal elemental variations, health risk assessment and conservational management. Frontiers in Life Science, 8(1), 71-96.

DKP Kabupaten Karangasem. (2016). Jumlah Kelompok Nelayan Di Kabupaten Karangasem. Amlapura, Indonesia: Dinas Kelautan dan Perikanan Kabupaten Karangasem.

BPS Kabupaten Karangasem. (2016). Kabupaten Karangasem Dalam Angka 2015. Amlapura, Indonesia: Badan Pusat Statistik Kabupaten Karangasem. 
Basrowi, B., \& Juariyah, S. (2010). Analisis Kondisi Sosial Ekonomi dan Tingkat Pendidikan Masyarakat Desa Srigading, Kecamatan Labuhan Maringgai, Kabupaten Lampung Timur. Jurnal Ekonomi $\mathcal{E}$ Pendidikan, 7(1), 58-81.

Hajjej, G., Hattour, A., Allaya, H., Jarboui, O., \& Bouain, A. (2010). Biology of little tunny Euthynnus alletteratus in the Gulf of Gabes, Southern Tunisia (Central Mediterranean Sea). Revista de biología marina y oceanografía, 45(3), 399-406.

Hendiarti, N., Suwarso, S., Aldrian, E., Amri, K., Andiastuti, R., Sachoemar, S. I., \& Wahyono, I. B. (2005). Seasonal Variation of Pelagic Fish Catch Around Java. Oceanography, 18(4), 112-123.

Ilhamdi, H., Telussa, R., \& Ernaningsih, D. (2016). Analisis tingkat pemanfaatan dan musim penangkapan ikan pelagis di Perairan Prigi Jawa Timur. Jurnal Ilmiah Satya Mina Bahari, 1(1), 52-64.

Johnson, M. G., \& Tamatamah, A. R. (2013). Length frequency distribution, mortality rate and reproductive biology of kawakawa (Euthynnus affinis-Cantor, 1849) in the coastal waters of Tanzania. Pakistan journal of biological sciences: PJBS, 16(21), 12701278.

Mustaruddin. (2012). Pengembangan Perikanan Tangkap yang Bersinergi Dengan Aspek Lingkungan dan Sosial Ekonomi: Studi Kusus di Perairan Kabupaten Banyuwangi. Jurnal Ilmu Pertanian dan Perikanan, 1(1), 17-29.

Pontoh, O. (2011). Pengaruh Tingkat Pendapatan Terhadap Pola Konsumsi Nelayan di Kecamatan
Tenga Kabupaten Minahasa Selatan, Sulawesi Utara. Pacific Journal, 1(6), 1038-1040.

Prayoga, I. M. S., Putra, I. D. N. W., \& Dirgayusa, I. G. N. P. (2017). Pengaruh Sebaran Konsentrasi Klorofil-a Berdasarkan Citra Satelit terhadap Hasil Tangkapan Ikan Tongkol (Euthynnus sp) Di Perairan Selat Bali. Journal of Marine and Aquatic Sciences, 3(1), 30-46.

Rasyid, J. A. (2013). Distribusi Suhu Permukaan pada Musim Peralihan Barat-Timur Terkait dengan Fishing Ground Ikan Pelagis Kecil di Perairan Spem onde. Jurnal Ilmu Kelautan dan Perikanan, 20(1), 1-7.

Sompie, M. S. (2011). Perikanan Tongkol Di Perairan Buyat Pante. Jurnal Perikanan Dan Kelautan Tropis, 7(2), 87-92.

Sulistyaningsih, R. K., Jatmiko, I., \& Wujdi, A. (2014). Length Frequency Distribution and Population Parameters of Kawakawa (Euthynnus affinis-Cantor, 1849) Caught by Purse Seine in the Indian Ocean (a Case Study in Northwest Sumatera IFMA 572). Fourth Session of IOTC Working Party on Neritic Tuna (WPNT04). 29 June - 2 July, 2014. Phuket, Thailand. IOTC 2014 WPNT04-20.

Wasak, M. (2012). Keadaan Sosial-Ekonomi Masyarakat Nelayan di Desa Kinabuhutan Kecamatan Likupang Barat. Kabupaten Minahasa Utara, Sulawesi Utara. Pacific Journal, 1(7), 1339-1342.

Yuniarta, S., van Zwieten, P. A., Groeneveld, R. A., Wisudo, S. H., \& van Ierland, E. C. (2017). Uncertainty in catch and effort data of small-and medium-scale tuna fisheries in Indonesia: Sources, operational causes and magnitude. Fisheries Research, 193, 173-183.

(C) 2017 by the authors; licensee Udayana University, Indonesia. This article is an open access article distributed under the terms and conditions of the Creative Commons Attribution license (http://creativecommons.org/licenses/by/3.0/). 